\title{
Embryo and larval development of the yellow clam Mesodesma mactroides (Reeve, 1854) (Mesodesmatidae) in laboratory
}

\author{
JUAN J.S. SANTOS, JULIANA P. BERNARDES, JUAN R.B. RAMÍREZ, CÁSSIO O. \\ RAMOS, CARLOS HENRIQUE A. DE MIRANDA GOMES \& LUIS ALBERTO ROMANO
}

\begin{abstract}
The yellow clam Mesodesma mactroides (Reeve, 1854) is a sand mollusc with historical and socioeconomic importance in Brazil, Uruguay and Argentina. A guaranteed form to access a successful reestablishment of the species in their natural environment is directly linked to their reproduction biology. Then, our report introduces the embryonic and larval development of the yellow clam reared in laboratory for such purposes. M. mactroides broodstock were selected as specimens who possess a mean total shell length and weight of $66 \pm 3.82 \mathrm{~mm}$ and $27.15 \pm 4.07 \mathrm{~g}$ for an afterwards spawn induction through stripping technique. Regarding the embryonic development, newly fertilized oocytes exhibited a mean diameter of $51.20 \pm 6.64 \mu \mathrm{m}$. The first polar corpuscle, trochophores and D-veliger appeared at $20 \mathrm{~min}, 18$ and $24 \mathrm{~h}$ after fertilization, respectively. Umbonate and pediveliger larvae were noticed on the $8^{\text {th }}$ and $25^{\text {th }}$ day, respectively, with complete metamorphosis occurring only at the $27^{\text {th }}$ day, when all larvae were retained in a $200 \mu \mathrm{m}$ nylon mesh. Therefore, with that basic understanding of the embryonic and larval development of M. mactroides in the laboratory, forwards studies will focus in establish a technological package for this species.
\end{abstract}

Key words: broodstock, D-veliger, M. mactroides, pediveliger, sand mollusk, stripping.

\section{INTRODUCTION}

Mesodesmatidae is a socioeconomically important family of sand molluscs throughout the world, including promising species for aquaculture (Santos et al. 2016) such as toheroa (Paphies ventricosa) (Redfearn 1982, Gadomski et al. 2015) and pipi (Paphies australis) (Hooker 1997) in New Zealand, macha (Mesodesma donacium) (Uriarte 2008, Ayerbe et al. 2017) in Chile and Peru, and the yellow clam Mesodesma mactroides (Reeve, 1854) in southern South America. M. mactroides is distributed from the coast of Rio de Janeiro, Brazil to Buenos Aires, Argentina (Rios 1994), standing out for its historical fishing value in these regions (Coscarón
1959, McLachlan 2018). Excessive extraction and massive mortalities drastically reduced their populations (Carvalho et al. 2013a, b, Santos et al. 2016), but the actual causes of mortalities are unknown. In the face of a threatening status, it is important to develop strategies to manage and increase their natural stocks (Gianelli et al. 2015).

The cultivation of yellow clam in the laboratory has been considered an option to foster repopulation programs and aquaculture activities, as it has already occurred with M. donacium in Peru (Ayerbe et al. 2017). However, the knowledge about the cultivation of $M$. mactroides, as many other tropical native species with commerce potential, is still lacking. 
Developing culture methods for $M$. mactroides would be beneficial, as reduce the pressure on natural populations and would increase coastal productivity (Cáceres-Martínez \& VásquezYeomans 2008, López et al. 2008).

Previous studies on pathogen prevalence, anthropogenic influence, seasonality (Carvalho et al. 2013a, b, Santos et al. 2016), salinity tolerance, histopathology and immunology (Carvalho et al. 2015a, b, 2016) have been carried out to comprehend the environmental behavior of M. mactroides. To cultivate a new species, it is important to understand its biological and ecological requirements and provide adequate simulation of environmental conditions in the laboratory for a better performance in subsequent cultivation systems (Urban 2000, Madrones-Ladja 2002, Huo et al. 2014). In this sense, little is known about the embryonic and larval development of $M$. mactroides in laboratory. Thus, our study describes the morphology and growth during the embryonic and larval development of the yellow clam M. mactroides under laboratory conditions, contributing to develop the technological package for this species.

\section{MATERIALS AND METHODS}

\section{Laboratory collection and conditioning procedures}

Fifty adult specimens of $M$. mactroides were collected in April 2017 (autumn season), during a low tide in the tidal zone of Mar Grosso beach, in the municipality of São José do Norte, Rio Grande do Sul, Brazil ( $32^{\circ} 3^{\prime} 10^{\prime \prime} S$ 51 $59^{\prime} 26^{\prime \prime} \mathrm{W}$ ). The animals were stored in 20-liter containment basins at room temperature and transported to the Laboratory of Marine Molluscs at the Universidade Federal de Santa Catarina, Brazil (LMM - UFSC).
The animals were acclimatized in 5-liter buckets containing sand ( $3 \mathrm{~kg}$ ) and transferred to 40 -liter tanks with a temperature of $18{ }^{\circ} \mathrm{C}$, aeration and continuous flow of seawater (35 ppt). The diet of the broodstock was a microalgae mix composed of Chaetoceros muelleri, Isochrysis galbana and Rhodomonas salina (1:1:1) at the concentrations of 15 to 20 $\times 10^{4}$ cellsmL ${ }^{-1}$ daily. The average total shell length and weight of the broodstock specimens selected for this experiment were $66 \pm 3.82 \mathrm{~mm}$ and $27.15 \pm 4.07 \mathrm{~g}$, respectively.

\section{Spawning induction}

At the end of the third week of conditioning, spawning inductions were attempted thorough three different methodologies: two thermal inductions with a gradually raising temperature and an abrupt thermal shock, as well as a stripping technique.

The thermal induction with gradually increasing temperature method consisted of an acclimatization of 40 broodstock specimens in a tank (200 L) with continuous water flow and salinity of 35 ppt to a temperature gradually increasing from 18 to $26{ }^{\circ} \mathrm{C}$ during 9 hours. The second method of thermal induction was a shock method that consisted in exposing 40 broodstock specimens acclimated at $18{ }^{\circ} \mathrm{C}$ in a 2,500 L tank with mild aeration to an abrupt increase in the temperature $\left(23.5^{\circ} \mathrm{C}\right)$ for 15 hours (overnight). The tanks contained a mesh sieve of $18 \mu \mathrm{m}$ at the water outlet to retain female gametes.

The spawning was performed using the stripping method, using eight specimens of $M$. mactroides evaluated under optical microscopy to certify the presence of viable gametes (Helm et al. 2004). The proportion of males and females used in this procedure was 1:1. Prior to the fertilization, the pooled eggs $(10,000,000)$ 
were sieved and mixed in $15 \mathrm{~L}$ of seawater with sperm added (1:7).

The analysis of embryogenic and larval development was proceeded after fertilization. The zygotes obtained with the most efficient spawning method were selected for morphological evaluation.

\section{Embryonic development}

After fecundation, the embryos were transferred to a 2,500-liter flat-bottomed tank at the density of 4,000 embryos $\mathrm{L}^{-1}$, with seawater previously filtered and UV-sterilized, temperature of $25 \pm 1$ ${ }^{\circ} \mathrm{C}$, salinity of $32 \mathrm{ppt}$ and mild aeration. Embryos were monitored through their development and morphological analyses determining all embryonic phases lasted until they reached the D-veliger larva stage. Samples were taken at 5-minute intervals in the first hour after fertilization, 30-minute intervals for 8 hours and every 3 hours until completing 24 hours, using a $2 \mathrm{~mL}$ pipette and observed under a SedgewickRafter chamber.

\section{Larval development}

The D-veliger larvae were transferred to a 4,000-liter flat-bottomed tank, with salinity of $32 \mathrm{ppt}$ and mild aeration. Everyday, the water was completely renewed, the temperature was recorded before and after water exchanges, and the larvae were sieved with mesh sizes ranging from $35 \mu \mathrm{m}$ at the beginning to $200 \mu \mathrm{m}$ at the end of cultivation, with samples being collected for morphometric analysis. The larvae were initially fed with $1 \times 10^{4}$ cellsmL ${ }^{-1}$ of Chaetoceros calcitrans, Isochrysis galbana and Pavlova lutheri (ratio: 0.30: $0.35: 0.35 \times 10^{4}$ cellsmL $^{-1}$, respectively), increasing to $2 \times 10^{4}$ cellsmL ${ }^{-1}$ with the addition of

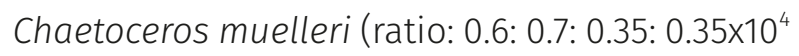
cellsmL ${ }^{-1}$, respectively). The larvae growth was monitored daily by measuring shell length and height of 10 to 20 specimens. After the previous observation verifying survival and motility, samples were fixed in $4 \%$ buffered formaldehyde for later analysis under optical microscopy. When all larvae reached the pediveliger stage and were retained at 200- $\mu \mathrm{m}$ meshes, they were ready to settle and the larviculture phase was considered to be completed

\section{Morphometric analyses}

Growth averages and standard deviation ( \pm SD) (embryonic phase: diameter, larval phase: larval height and length) and morphology (cell divisions and structural development) were evaluated in living and preserved specimens under the $\mathrm{x} 40$ objective on a Carl Zeiss ${ }^{\circledR}$ microscope (Axio Imager A2) and Leica ${ }^{\circledR}$ DM500 (connected with the Leica LAZ EZ software) for embryonic and larval stages, respectively.

\section{Statistics}

Height and length of embryos and larvae were analyzed through Generalized Linear Model after the assumptions of normality and homoscedasticity were confirmed. Regression analyses were made to evidence patterns of the data as a function of time. The regression model was selected based on the determination factor $\left(r^{2}\right)$. Growth was calculated as a function of the accumulated mean temperature values for each experimental day to evaluate the influence of temperature changes over time on the larval development (Degrees/Day). The analyses were performed using the software GraphPad Prism 6.

\section{RESULTS}

\section{Spawning induction}

From the three techniques used to obtain embryos, it was observed that both thermal induction with gradual increase of temperature and exposure to thermal shock were unsuccessful. However, the stripping technique 
showed a positive result for collecting gametes containing a visible germinal vesicle, which confirmed the fertilization.

\section{Embryonic development}

The different stages and morphological changes over time of $M$. mactroides embryos ( $n=10$ specimens) are shown in Table I and Figure 1. The newly fertilized oocytes had a spherical shape, with a mean diameter of $51.20 \pm 6.64 \mu \mathrm{m}$ (Figure 1a). Twenty minutes after fertilization, the first polar corpuscle was formed (Figure 1b). In the next 3 hours, rapid changes occurred, such as: the formation of the second polar corpuscle, first embryonic division, formation of the 2-cell embryo, and initial divisions until the multi-division phase (Figure 1c-h). Blastula and gastrula appeared within 4 and 5 hours after the fertilization, respectively (Figure $1 \mathrm{i}, \mathrm{j}$ ). Between 8-10 hours, the development of the first cilia was noticeable and the cells began the movements of slight rotation and swimming (Figure 1k). The first trochophore larvae with active swimming emerged after 18 hours (Figure 1l) with cilia growing over time, which allowed faster movements compared to the initial stages (Figure 1m, n). The first D-veliger larvae appeared at 24 hours (Figure 10).

Table I. Embryo stages of Mesodesma mactroides (Reeve, 1854) as a function of time, grown at $25 \pm 1{ }^{\circ} \mathrm{C}$ $(n=10)$.

\begin{tabular}{|c|c|}
\hline Stage & Post-fertilization time \\
\hline Fertilized oocyte & $10 \mathrm{~min}$. \\
\hline First polar corpuscle & $20 \mathrm{~min}$. \\
\hline 2-cell & $1 \mathrm{~h} 40 \mathrm{~min}$. \\
\hline 4-cell & $2 \mathrm{~h}$ \\
\hline 8-cell & $2 \mathrm{~h} 20 \mathrm{~min}$. \\
\hline Multicellular Stage & $3 \mathrm{~h}$ \\
\hline Blastula & $4 \mathrm{~h}$ \\
\hline Gastrula & $5 \mathrm{~h}$ \\
\hline Trochophore & $18 \mathrm{~h}$ \\
\hline D-larva & $24 \mathrm{~h}$ \\
\hline
\end{tabular}

\section{Larval development}

The larval growth of $M$. mactroides, including mean height and shell length as a function of time, is shown in Figure 2. The sequence of different stages of larval development with the average shell length are shown in Figure 3. The D-veliger stage is characterized by the presence of the first double transparent larval shell and the emergence of velum, which assists in swimming and feeding. Larvae had an initial mean height of $62.55 \pm 2.20 \mu \mathrm{m}$ and shell length of $79.69 \pm 3.47 \mu \mathrm{m}$, showing a straight hinge and a semicircular shape over time as a characteristic of umbo formation. This semicircle conformation of shells remained until they reached the pediveliger stage, in which the umbo became more prominently pronounced (Figure 3a-f).

The early umbonate larvae were observed on the $8^{\text {th }}$ day with average shell height and length of $116.24 \pm 1.29 \mu \mathrm{m}$ and $142.59 \pm 4.27 \mu \mathrm{m}$, respectively (Figure 3c). The larvae at this stage started to become rounded and the umbo was forming. The period between $10^{\text {th }}$ and $15^{\text {th }}$ day the shell height and length of larvae had enlarged from $140.03 \pm 14.47 \mu \mathrm{m}$ and $162.87 \pm 17.15 \mu \mathrm{m}$ to $182.47 \pm 29.54 \mu \mathrm{m}$ and $210.99 \pm 39.35 \mu \mathrm{m}$ (Figure 3d, e). After 25 days pos fertilization, the larvae showed a functional velum and a foot, reached the pediveliger stage (Figure $3 \mathrm{f}$ ) with a mean shell height and length of $237.92 \pm 19.86 \mu \mathrm{m}$ and 281.11 $\pm 27.43 \mu \mathrm{m}$. At this stage the larva was able to crawl or swim. Throughout larval development, the spot that characterizes an eyed larva was not observed as a pattern for sand molluscs.

On the $27^{\text {th }}$ day, the larvae reached a mean height and shell length of $255.94 \pm 14.22 \mu \mathrm{m}$ and $295.14 \pm 13.17 \mu \mathrm{m}$, respectively, being retained in the $200-\mu \mathrm{m}$ nylon mesh. The velum was withdrawn and the activity of the foot (dense muscle tissue in the shape of an arrow) was intense, showing a crawling behavior in search for the sediment, which characterizes settlement 

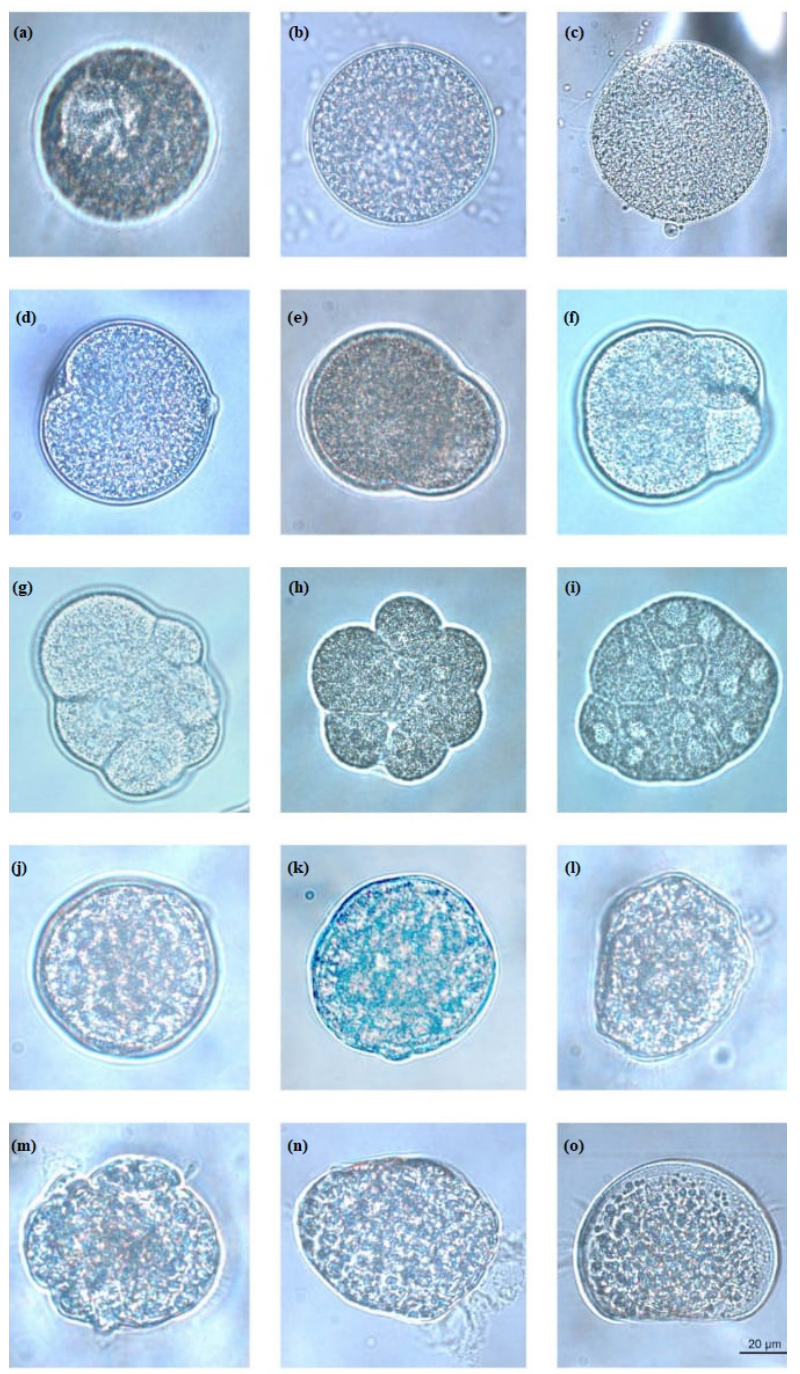

Figure 1. Embryonic developmental stages of Mesodesma mactroides: (a) oocyte; (b) oocyte fertilized with first polar corpuscle; (c) second polar corpuscle; (d) first embryonic division; (e) 2-cell embryo; (f) initial divisions; (g) multiple divisions; ( $h$ ) multiple divisions; (i) blastula; (j) gastrula; (k) first cilia and swimming movement; $(\mathrm{l})$ trochophore; $(\mathrm{m})$ trochophore; ( $n$ ) trochophore; (o) D-veliger stage.

activity. After metamorphosis was observed the development of gill arches and growth lines (Figure 3g).

Statistical analyzes demonstrated positive larval development through biometric variables of height and length as a function of time (Figure 2).

\section{Temperature}

The temperature of cultivation during the embryonic phase was maintained at $25^{\circ} \mathrm{C}$, while the average temperature during larviculture was $20.0 \pm 1.8{ }^{\circ} \mathrm{C}$, with minimum and maximum variations ranging from 16.5 to $24.5{ }^{\circ} \mathrm{C}$ (Figure $2 d)$. Although the experimental temperature was tried to set at $25^{\circ} \mathrm{C}$ as an experimental constant, there were environmental variations during the experimental time that produced considerable temperature variations. Calculating the correlation coefficient between the specific growth rate $\left(\ln \mathrm{H}_{\mathrm{f}}-\ln \mathrm{H}_{\mathrm{i}} / \mathrm{t}\right)$ and the temperature, it was not possible to find a statistical interaction between the strong variables $(r=0.16 p>0.06)$. evaluating the possibility of using temperature as a growth correction factor observed within the experiment, the degrees*hour for each experimental day were calculated, a regression analysis was performed that discarded the linear model $\left(r^{2}=0.4 p>0.05\right)$ as a descriptor of the behavior and a quadratic model was applied for the data, which presented the highest adjustment compared with other non-linear models $\left(r^{2}=0.91 p<0.05\right.$; Figure $\left.2 e\right)$, which rules out correction by degrees*hour as a correction factor and dismisses the range of temperatures presented in this experiment as a significant factor of variation (Stinner et al. 1974).

\section{DISCUSSION}

The successful collection of mature gametes during the gonadal stage is the key factor to control spawning and reproduction in the laboratory (Reverol et al. 2004). In a previous study with $M$. mactroides in Argentina, two spawning events occurred in the spring and summer of one year (Herrmann et al. 2009). Accordingly, the broodstock in our study was collected during the autumn and similarly displayed mature condition for reproduction. This is an advantage for cultivating yellow clams 
and rearing juveniles in laboratory, which is also observed by Hooker (1997) with Paphies australis. However, information on what triggers spawning in M. mactroides is still lacking.

This is the first study regarding embryonic and larval development of $M$. mactroides in laboratory, adding essential information about the biology of Mesodesmatidae (Gadomski et al. 2015). Coscarón (1959) provided a partial illustration about the embryonic stage and young larvae specimens from planktonic samples of the environment, although the identification of species was uncertain. In addition, metamorphosis to D-veliger, in that case, did not reach its completion in laboratory. Indirect methods used by Coscarón (1959), such as abundance of the larvae in planktonic samples from the environment can lead to (a)

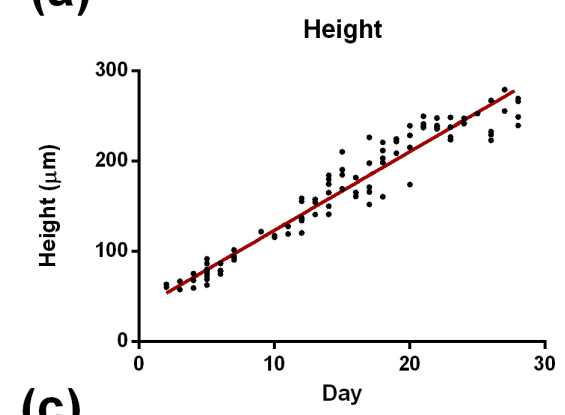

$$
\text { (c) }
$$

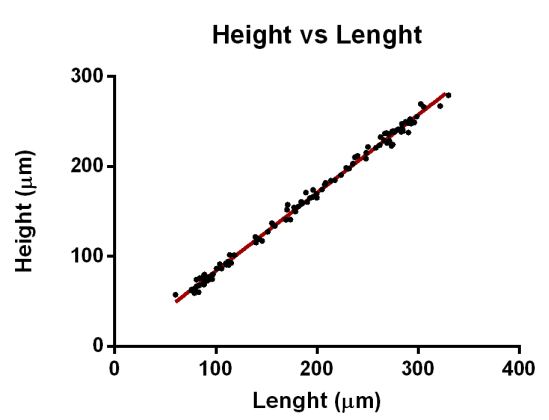

(b)

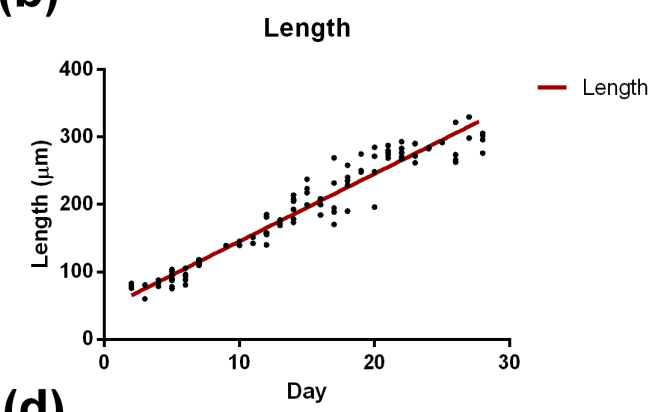

(d)

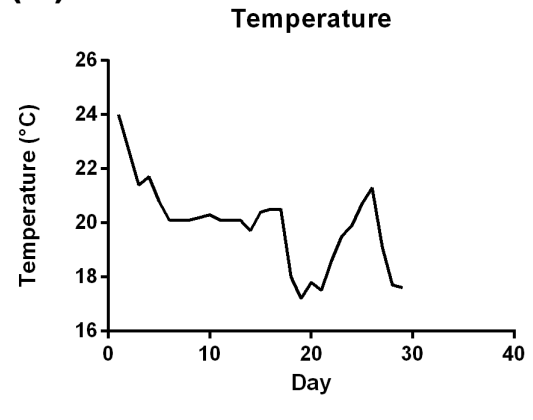

(e)

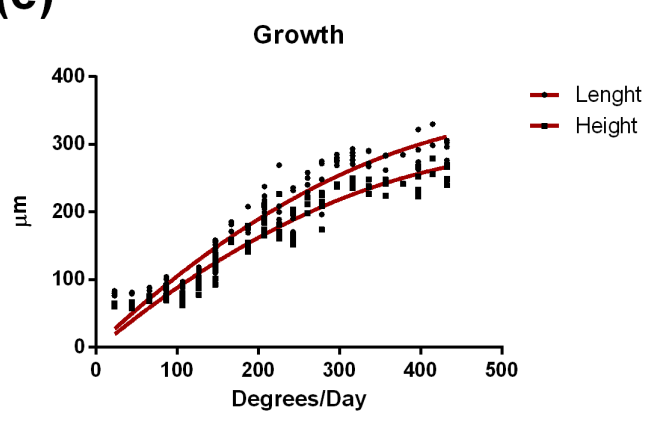

Figure 2. Larval growth data of the species Mesodesma mactroides: regressions for growth data as a function of time in degrees* day. (a) Height $=31.05 \pm 0.92 ;$ Day $+12.07 \pm 15.51 ; r^{2}=0.91 ; p<0.0001$. (b) Length = 35.78 $\pm 1.1 ;$ Day $+16.66 \pm 18.0 ; r^{2}=0.91 ; p<0.0001$. (c) Height $=0.86 \pm 0.005$ Length $=1.298 \pm 2.96 ; r^{2}=0.99 ; p<0.0001$. (d) Average temperatures in the experimental period. (e) Length $=2.5 \pm 0.11$ degrees* day $+33.88 \pm 24.66 ; r^{2}=0.91 ; p<0.0001$, Height $=2.17 \pm 0.09$ degrees* day $+27.09 \pm 21.33 ; r^{2}=0.91 ; p<0.0001$. 


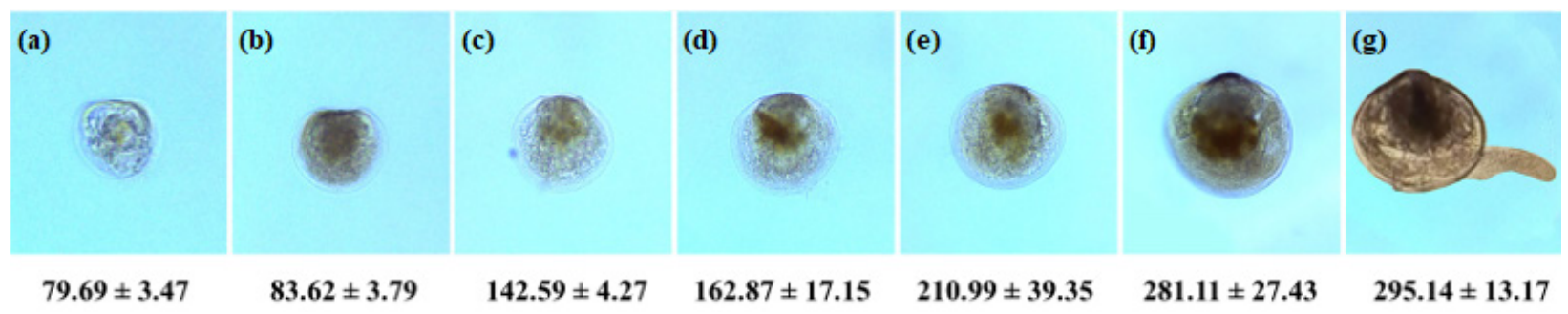

Figure 3. Larval development of Mesodesma mactroides. Mean ( \pm SD) of shell length $(\mu \mathrm{m})$ in the period of 27 days. (a) D-veliger, $1^{\text {st }}$ day; (b) D-veliger $2^{\text {nd }}$ day; (c) early umbonate larvae, $8^{\text {th }}$ day; (d) umbonate larvae, $10^{\text {th }}$ day; (e) umbonate larvae, $15^{\text {th }}$ day; (f) pediveliger, $25^{\text {th }}$ day; and $(\mathrm{g})$ pediveliger, $27^{\text {th }}$ day.

incorrect identification (Hooker 1997), since the identification of larvae by plankton samples is only precise when direct techniques are used, e.g. cultivation of the larvae in laboratory.

Coscarón (1959) observed that the size of mature oocytes ranged from 50 to $55 \mu \mathrm{m}$, similar to our results with $M$. mactroides (mean diameter \pm SD of $51.20 \pm 6.64$; Figure 1a), smaller than other Mesodesmatidae species, which possess a diameter ranging from 60 to $73 \mu \mathrm{m}$ (Gadomski et al. 2015). Apart from that, information concerning the chronology of events after fertilization, e.g. knowledge about the release time of the first polar corpuscle (Table I, Figure 1b), might be the basis for future studies with the yellow clam, including research related to triploid induction. We also observed the occurrence of metamorphosis into D-veliger stage in 24 hours, which was similar to the embryonic development of other species of Mesodesmatidae ranging from 22 to 45 hours, as described in Table II.

The larval development period varied from 17 to 31 days among species from the Mesodesmatidae family and it lasted 27 days in our study (Table II). Morphologically, the larval development of M. mactroides (Figure 3) was similar to the larval description of $P$. ventricosa (Gadomski et al. 2015) and M. donacium (Ayerbe et al. 2017). This leads to the belief that such characteristics are representative of this family, e.g. the modifications of D-veliger into umbonated larvae, with round shape and an active velum, and the development of pediveliger larvae, with loss of the velum and presence of an initially retracted foot that becomes more active and functional after some time. However, the size of the total height and total length of the shells changed over time among P. ventricosa (Redfearn 1982, Gadomski et al. 2015), P. subtriangulata (Redfearn 1987) and P. australis (Hooker 1997) in the different stages of development (Table II).

The final shell length of pediveliger larvae (295.14 $\mu \mathrm{m}$ ) was similar to P. ventricosa (270$300 \mu \mathrm{m}$ ) (Redfearn 1982) and larger than $P$. subtriangulata (230-260 $\mu \mathrm{m})$ (Redfearn 1987) and P. australis (264.70 $\mu \mathrm{m}$ ) (Hooker 1997) larvae (Table II). A similarity between M. mactroides and $P$. ventricosa was also observed in the slow development of pediveligers (27d and 22-31d respectively) compared to other representatives of this family (Table II). Gadomski et al. (2015) demonstrated that different temperatures directly affected the rate of embryonic and larval development of $P$. ventricosa, settling after 22 to 31 days. These authors reported that the rate of larval development depends on countless variables besides temperature, where phylogenetic differences may also contribute to slow or moderate rates of development, possibly assigning these traits to representatives of the Mesodesmatidae family. Mesodesmatidae species generally complete 


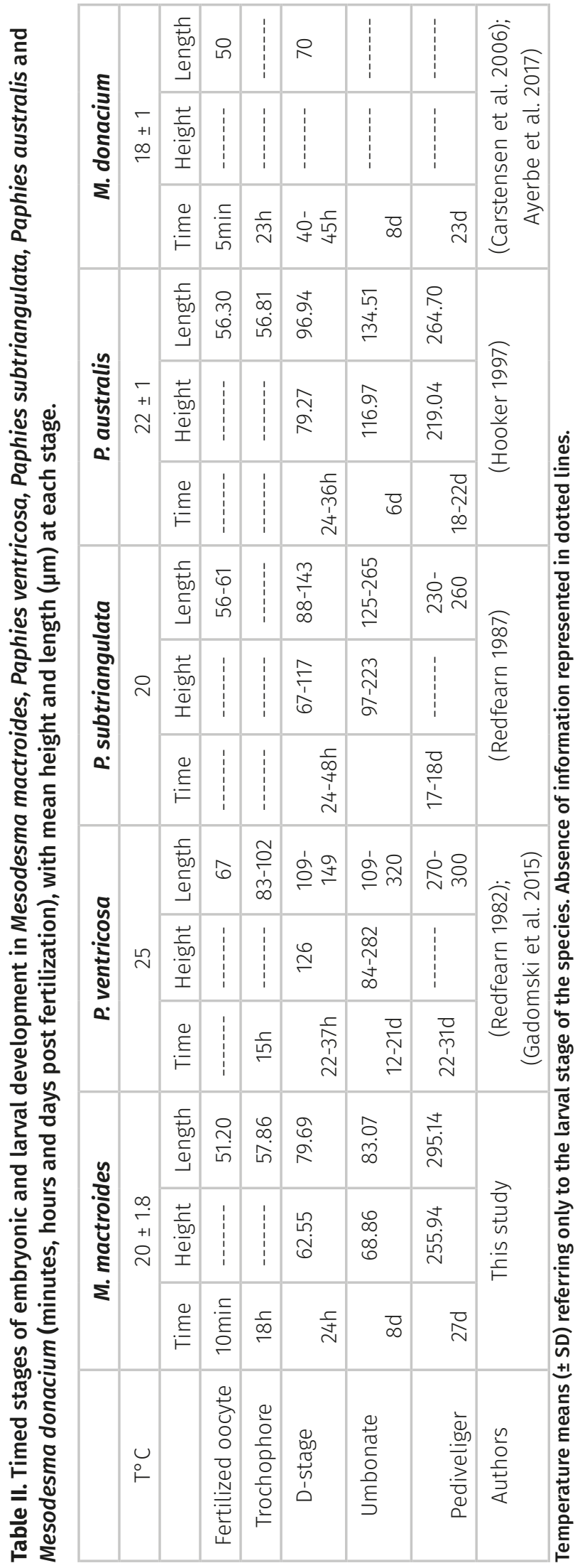

An Acad Bras Cienc (2020) 92(suppl.1) e20190053 8| 11 
their larval development in two to 3 weeks, like P. subtriangulata (17-18d), P. australis (18-22d); and $M$. donacium (23 d) according to Table II.

As previously mentioned, temperature is a determining factor for larval development time in bivalve molluscs (Huo et al. 2017). In the present study, the larviculture was performed at room temperature, and it was not possible to gauge the extent to which this variable was decisive at the end of the experiment (Figure 2 ), which had a duration of 27 days with live larvae, metamorphosed in pediveliger and ready for settlement. A preliminary descriptive study of the embryonic and larval development of Mesodesma donacium, with temperature controlled at $17{ }^{\circ} \mathrm{C}$, lasted for 28 days with $100 \%$ mortality (Carstensen et al. 2006).

Salinity is another limiting factor for the embryonic and larval development of bivalves (Madrones-Ladja 2002) and fluctuations between 14 and 38 ppt affect environments where the yellow clam inhabits (Odebrecht et al. 2010). Although the juveniles and adults of this species are considered euryhaline, tolerating salinities ranging from 15 to $35 \mathrm{ppt}$ (Carvalho et al. 2015b), it is uncertain if this could be applied with the embryonic and larval development in laboratory. In addition, salinity information was not mentioned in studies with other species of Mesodesmatidae. In this sense, we used a salinity of $32 \mathrm{ppt}$, which is close to the mean values found by Santos et al. (2016) in specific and seasonal analyses in places of occurrence of the yellow clam, which remained adequate until the end of the experiment.

These results provide an understanding of the embryonic and larval development of this species, serving as a basis for future research, e.g. effect of salinity and temperature on the survival and yield of embryos and larvae, as well as studies related to diets, in order to establish a complete technological package for this species.

\section{CONCLUSION}

This experiment showed that spawning using the stripping method is efficient for obtaining viable gametes. The distinct phases of embryonic and larval development present in this study demonstrated similar pattern to species from Mesodesmatidae. These findings ensure viability on production of $M$. mactroides juveniles after the period of 27 days of larval rearing at specific condition of temperature and salinity.

\section{Acknowledgments}

The authors would like to thank Coordenação de Aperfeiçoamento de Pessoal de Nivel Superior (CAPES) for the financial support. L.A. Romano is a researcher at Brazilian Conselho Nacional de Desenvolvimento Científico e Tecnológico (CNPq - 301245 / 2016-9).

\section{REFERENCES}

AYERBE R, ZEVALLOS S, CASTAÑEDA V, LOPE F, BENDITA H \& SANZ Y. 2017. Manual para el cultivo de la macha Mesodesma donacium (LAMARCK, 1818) en la région Moquega. Instit del Mar del Perú, Callao, 24 p.

CÁCERES-MARTÍNEZ J \& VÁSQUEZ-YEOMANS R. 2008. La patología en moluscos bivalvos: principales problemas y desafíos para la producción de bivalvos en América Latina. In: Lovatelli A, Farías A and Uriarte I (Eds), Estado actual del cultivo y manejo de moluscos bivalvos y su proyección futura: factores que afectan su sustentabilidad en América Latina. Taller Técnico Regional de la FAO. 20-24 de agosto de 2007, Puerto Montt, Chile. FAO Actas de Pesca y Acuicultura. No. 12. Roma, FAO, p. 327-337.

CARSTENSEN D, OLIVA M, SIELFELD W \& LAUDIEN J. 2006. LarVal development of Mesodesma donacium (Macha). XXVI Congreso de Ciencias del Mar, Iquique, Chile.

CARVALHO YB, JETHRO J, POERSCH LH \& ROMANO LA. 2015a. India ink induces apoptosis in the yellow clam Mesodesma mactroides (Deshayes, 1854). Optical and ultrastructural study. An Acad Bras Cienc 87: 1981-1989.

CARVALHO YB, SANTOS JJS, RAIBENBERG FR, POERSCH LH \& ROMANO LA. 2016. Use of polymerase chain reaction for bivalve pathogen surveillance in the yellow clam Mesodesma mactroides. I Aquat Anim Health 28(2): 114-117. 
CARVALHO YBM, POERSCH LH, JUNIOR JP \& ROMANO LA. 2013b. Histopathological survey of the yellow clam Mesodesma mactroides from southern Brazil. Bull Eur Ass Fish Pathol 33(2): 53-58.

CARVALHO YBM, POERSCH LH \& ROMANO LA. 2013a. Rickettsia associated mortality of the yellow clam Mesodesma mactroides (Bivalvia: Mesodesmatidae) in southern Brazil. Malacologia 56 (1-2): 301-3017.

CARVALHO YBM, ROMANO LA \& POERSCH LHS. 2015b. Effect of low salinity on the yellow clam Mesodesma mactroides. Braz J Biol 75(1): 8-12.

COSCARÓn S. 1959. La almeja amarilla (Mesodesma mactroides, Deshayes) de la costa de la Provincia de Buenos Aires. Agro Publ Tec 1(3): 1-66.

GADOMSKI K, MOLLER H, BEENTJES M \& LAMRE M. 2015. Embryonic and larval development of the New Zealand bivalve Paphies ventricosa Gray, 1843 (Veneroida: Mesodesmatidae) at a range of temperatures. J Mollus Stud 81(3): 356-364.

GIANELLI I, MARTÍNEZ G \& DEFEO O. 2015. An ecosystem approach to small-scale co-managed fisheries:the yellow clam fishery in Uruguay. Mar Policy 62: 196-202.

HELM MM, BOURNE N \& LOVATELLI A. 2004. Hatchery culture of bivalves: a practical manual. FAO Fisheries Technical Paper. N 471, Rome, FAO.

HERRMANN M, ALFAYA JE, LEPORE ML, PENCHASZADEH PE \& LAUDIEN J. 2009. Reproductive cycle and gonad development of the Northern Argentinean Mesodesma mactroides (Bivalvia: Mesodesmatidae). Helgol Mar Res 63: $207-218$.

HOOKER SH. 1997. Larval and postlarval development of the New Zealand pipi Paphies australis (Bivalvia: Mesodesmatidae). Bull Mar Sci 61(2): 225-240.

HUO Z, WANG Z, LIANG J, ZHANG Y, SHEN J, YAO T, SU J \& YU R. 2014. Effects of salinity on embryonic development, survival, and growth of Crassostrea hongkongensis. J Ocean Univ China 13(4): 666-670.

HUO ZM, GUAN HW, RBBANI MG, XIAO YX, ZHANG XK, FAN C \& YAN XW. 2017. Effects of environmental factors on growth, survival, and metamorphosis of geoduck clam (Panopea japonica A. Adams, 1850) larvae. Aquaculture Reports 8: 31-38.

LÓPEZ DA, LOPEZ BA \& GONZALEZ ML. 2008. Shellfish culture in Chile. Int J Environ Pollut 33(4): 401-431.

MADRONES-LADJA JA. 2002. Salinity effect on the embryonic development, larval growth and survival at metamorphosis of Placuna placenta Linnaeus (1758). Aquaculture 214(1-4): 411-418.
MCLACHLAN A. 2018. Fisheries. In: McLachlan A and Defeo O. The Ecology of Sandy Shores. Academic Press 14: 331-372.

ODEBRECHT C, BERGESCH M, RÖRIG LR \& ABREU PC. 2010. Phytoplankton interannual variability at Cassino Beach, Southern Brazil (1992-2007), with emphasis on the surfzone diatom Asterionellopsis glacialis. Estuar Coast 33(2): 570-583.

REDFEARN P. 1982. Larval shell development of the toheroa, Paphies ventricosa (Gray 1843) (Mactracea: Mesodesmatidae). New Zeal J Mar Fresh 16(3-4): 241-252..

REDFEARN P. 1987. Larval shell development of the northern tuatua, Paphies subtriangulata (Bivalvia, Mesodesmatidae). New Zeal J Mar Fresh 21(1): 65-70.

REVEROL YM, DELGADO JG, DE SEVEREYN YG \& SEVEREYN HJ. 2004. Embrionary and larval development of the marine clam Tivela mactroides (Bivalvia: Veneridae) in Zulia State, Venezuela. Rev Biol Trop 52(4): 903-909.

RIOS EC. 1994. Sea shell of Brazil. Rio Grande, Fundação Universidade Rio Grande, 368 p.

SANTOS JJS, CARVALHO YB, LOPES DLA \& ROMANO LA. 2016. Immunological profile of the yellow clam Mesodesma mactroides (Mesodesmatidae) from the southern coast of Rio Grande do Sul, Brazil. J Aquat Anim Health 28(1): $11-20$.

STINNER RE, GUTIERREZ AP \& BUTLER GD. 1974. An algorithm for temperature-dependent growth rate simulation. Can Entomol 106(05): 519-524.

URBAN HJ. 2000. Culture potential of the pearl oyster (Pinctada imbricata) from the Caribbean. I. Gametogenic activity, growth, mortality and production of a natural population. Aquaculture 189(3-4): 361-373.

URIARTE I. 2008. Estado actual del cultivo de moluscos bivalvos en Chile. In: Lovatelli A, Farías A and Uriarte I (Eds), Estado actual del cultivo y manejo de moluscos bivalvos y su proyección futura: factores que afectan su sustentabilidad en América Latina. Taller Técnico Regional de la FAO. 20-24 de agosto de 2007, Puerto Montt, Chile. FAO Actas de Pesca y Acuicultura. No. 12. Roma, FAO, p. 61-75.

\section{How to cite}

SANTOS JJS, BERNARDES JP, RAMÍREZ JRB, RAMOS CO, DE MIRANDA GOMES CHA \& ROMANO LA. 2020. Embryo and larval development of the yellow clam Mesodesma mactroides (Reeve, 1854) (Mesodesmatidae) in laboratory. An Acad Bras Cienc 92: e20190053. DOI 10.1590/00013765202020190053. 
Manuscript received on January 15, 2019;

accepted for publication on June 6, 2019

JUAN J.S. SANTOS ${ }^{1}$

https://orcid.org/0000-0001-8750-7856

JULIANA P. BERNARDES ${ }^{2}$

https://orcid.org/0000-0002-9676-363X

JUAN R.B. RAMÍREZ ${ }^{3}$

https://orcid.org/0000-0002-7594-1628

\title{
CÁSSIO O. RAMOS ${ }^{2}$
}

https://orcid.org/0000-0001-5485-5459

\section{CARLOS HENRIQUE A. DE MIRANDA GOMES ${ }^{2}$}

https://orcid.org/0000-0001-6533-9249

\author{
LUIS ALBERTO ROMANO ${ }^{1}$ \\ https://orcid.org/0000-0003-3144-3579 \\ ${ }^{1}$ Laboratório de Imunologia e Patologia de Organismos \\ Aquáticos/LIPOA, Universidade Federal do Rio Grande, \\ Caixa Postal 474, 96201-900 Rio Grande, RS, Brazil \\ ${ }^{2}$ Laboratório de Moluscos Marinhos/LMM, Universidade \\ Federal de Santa Catarina/UFSC, Rua dos Coroas, \\ 503, 88061-600 Florianópolis, SC, Brazil \\ ${ }^{3}$ Laboratório de Bioquímica Funcional de Organismos \\ Aquáticos/BIFOA, Universidade Federal do Rio Grande, \\ Caixa Postal 474, 96201-900 Rio Grande, RS, Brazil
}

Correspondence to: Juan Jethro Silva Santos

E-mail: juanjethrosantos@gmail.com

\section{Author contributions}

Juan Jethro Silva Santos performed the animal collection and all the experimental steps, as well, prepared figures and tables and wrote the paper. Juliana Portella Bernardes participated in the experimental stages in laboratory, morphological analysis and manuscript writing. Juan Rafael Buitrago Ramírez conducted the statistic, data analysis and reviewed drafts of the paper. Cássio de Oliveira Ramos, contributed to the animal collection phase and manuscript revision. Carlos Henrique Araujo de Miranda Gomes (co- advisor), participated and monitored all the experimental stages, contributing also to the writing of the manuscript. Luis Alberto Romano conducted the orientation of the activities, as well as contributed to the writing of the final manuscript. All authors revised the manuscript and approved the final version.

\section{(cc) BY}

